\title{
Kontribusi Kecerdasan Intrapersonal dan Sikap Tanggung Jawab Terhadap Kompetensi Pengetahuan IPS
}

\author{
K D. Windhu Dharmawan', I.W. Darsana² \\ ${ }^{123}$ Prodi Pendidikan Guru Sekolah Dasar, FIP \\ Universitas Pendidikan Ganesha, \\ Singaraja, Indonesia \\ e-mail: windhu.dharmawan.kadek@undiksha.ac.id ${ }^{1}$, iwayan.darsana@undiksha.ac.id ${ }^{2}$
}

\begin{abstract}
Abstrak
Penelitian ini bertujuan untuk mengetahui pengaruh yang signifikan kecerdasan intrapersonal dan sikap tanggung jawab terhadap kompetensi pengetahuan IPS siswa kelas V SD Gugus III Mengwi. Jenis penelitian adalah penelitian ex post facto dengan jenis studi korelasi. Populasi penelitian ini adalah siswa kelas V SD Gugus III Mengwi yang berjumlah 297 orang. Penentuan sampel menggunakan teknik proporsional random sampling dengan taraf signifikansi $5 \%$ banyak sampel adalah 164 orang. Penelitian ini menggunakan metode pengumpulan data yaitu metode non tes. Data kompetensi pengetahuan IPS diperoleh dari pencatatan dokumen sedangkan data kecerdasan intrapersonal dan sikap tanggung jawab diperoleh dengan menggunakan kuesioner/angket. Analisis uji prasyarat yang digunakan dalam penelitian ini ialah uji normalitas kolmogorov-smirnov, uji linieritas, uji multikolinieritas dan uji heterokesdastisitas. Selanjutnya data dianalisis denga uji hipotesis regresi linear sederhana dan regresi linear ganda. Hasil analisis data diperoleh $\mathrm{R}^{2}=0,061$ dan kontribusinya sebesar $6.1 \%$. Jadi kontribusi kecerdasan intrapersonal dan sikap tanggung jawab terhadap kompetensi pengetahuan IPS sebesar $6,1 \%$. Dapat disimpulkan kontribusi kecerdasan intrapersonal dan sikap tanggung jawab terhadap kompetensi pengetahuan IPS siswa kelas V SD Gugus III Mengwi Tahun Pelajaran 2018/2019 sebesar $6,1 \%$.
\end{abstract}

Kata Kunci: kecerdasan intrapersonal, sikap tanggung jawab

\begin{abstract}
The aimed of this research was to determine the significant effect of intrapersonal intelligence and responsibility on social studies knowledge competency on fifth grade elementary students of cluster III Mengwi. This research used ex post facto by using study of correlation. The population took all fifth grade elementary students of cluster III Mengwi which consisted of 297 students. The sample was taken by using proportional random sampling technique with $5 \%$ of significance 164 students as the sample. The data was collected by using non test method. The questionnaire was used to get the data of intrapersonal intelligence and responsibility. While the data of social-study knowledge competency collected by using document recording. The prerequisite test of this research used Kolmogorov-Smirnov normality test, linearity test, multicollinearity test, and heteroscedascity test. The data was analyzed by using simple linear regression and multiple linear regression analysis. The result of analysis found that $R^{2}=0,061$ and the contribution was $6,1 \%$. It could be concluded that the contribution of intrapersonal intelligence and the attitude of responsibility to the social studies knowledge competency on fifth grade elementary students of cluster III Mengwi in academic year 2018/2019 was 6.1\%.
\end{abstract}

Keywords: intrapersonal intelligence, responsibility

${ }^{*}$ Corresponding author.

Received 20 January 2020, Accepted 20 March 2020; Available online 5 Appril 2020 (C) 2020 MI All Rights Reserved 


\section{Pendahuluan}

Pendidikan merupakan kebutuhan primer bagi manusia yang mengalami perubahan dan perbaikan sesuai dengan perkembangan disegala bidang kehidupan. Upaya perubahan dan perbaikan tersebut bertujuan membawa kualitas pendidikan di Indonesia menjadi lebih baik. Perubahan dan perbaikan dalam bidang pendidikan meliputi berbagai komponen yang terlibat didalamnya, baik itu pelaksana pendidikan di lapangan (kompetensi guru dan kualitas tenaga pendidik), mutu pendidikan, perangkat kurikulum, sarana prasarana pendidikan, mutu manajemen pendidikan termasuk perubahan dalam metode dan strategi pembelajaran yang lebih inovatif. Menurut Peraturan Menteri Pendidikan Nasional Nomor 6 Tahun 2007 menyatakan bahwa, Pendidikan adalah usaha sadar dan terencana untuk mewujudkan suasana belajar dan proses pembelajaran agar siswa secara aktif mengembangkan potensi dirinya untuk memiliki kekuatan spiritual keagamaan, pengendalian diri, kepribadian, kecerdasan, akhlak mulia, serta keterampilan yang diperlukan dirinya, masyarakat, bangsa dan negara.

Menurut Ahmadi (2016:39) menyatakan definisi pendidikan bisa dilihat dari dua sudut pandang, yakni pendidikan sebagai proses dan pendidikan sebagai hasil. Sebagai proses, pendidikan didefinisikan sebagai suatu aktivitas interaksi manusia dengan lingkungannya. Sementara sebagai hasil, bahwa pendidikan merupakan perubahan hasil interaksi manusia dengan lingkungannya, yakni perubahan perilaku. Salah satu komponen dalam bidang pendidikan yang saat ini sedang mengalami perubahan dan perbaikan adalah kurikulum. Kurniasih (2014:2) menyatakan kurikulum adalah "seperangkat rencana dan pengaturan mengenai tujuan, isi dan bahan pelajaran serta cara yang digunakan sebagai pedoman penyelenggaraan kegiatan pembelajaran untuk mencapai tujuan pendidikan tertentu." Kurikulum 2013 sudah diterapkan di provinsi Bali namun belum semua sekolah menerapkannya, salah satu SD di kabupaten Badung yang sudah menerapkannya adalah SD di Gugus III Mengwi, Kurikulum 2013 lebih menekankan pada kompetensi dengan pemikiran kompetensi berbasis sikap, keterampilan, dan pengetahuan.

Kompetensi merupakan sesuatu yang kompleks, yang didalamnya mengandung banyak aspek. Kompetensi mencakup sikap, pengetahuan dan keterampilan. Berdasarkan observasi yang sudah dilaksanakan pada SD Gugus III Mengwi tahun pelajaran 2018/2019 nampaknya salah satu kompetensi yang masih perlu dioptimalkan adalah kompetensi pengetahuan IPS, hal tersebut dilihat dari nilai yang masih di bawah ketuntasan kriteria minimal (KKM) yaitu 65 yang telah ditentukan oleh sekolah. Kompetensi pengetahuan IPS adalah ilmu pengetahuan yang mempelajari tentang kehidupan sosial manusia, interaksi manusia dengan lingkunganya. Permendiknas No 22 tahun 2006 tentang Standar Isi menjelaskan ruang lingkup dari IPS itu sendiri meliputi : (1) Manusia, tempat dan lingkungan; (2) waktu, keberlanjutan dan perubahan; (3) sistem sosial dan budaya (4) perilaku ekonomi dan kesehjateraan. Dalam kompetensi IPS memiliki tujuan yang penting, yaitu mengembangkan pengetahuan, nilai, sikap keterampilan sosial, fakta, peristiwa, interaksi sosial dalam bermasyarakat bangsa dan negara. Selain itu, tujuan dari IPS bagi siswa menurut Permendiknas No 22 Tahun 2006 adalah untuk mengenalkan siswa dengan konsep-konsep yang berkaitan dengan kehidupan masyarakat dan lingkungan, memiliki kemampuan untuk berfikir logis, kritis agar memiliki komitmen, kesadaran terhadap nilai-nilai sosial, kemanusiaan serta memiliki kemampuan berkomunikasi, bekerja sama dan berkompetensi dalam masyarakat yang majemuk.

Namun adanya kesenjangan sekolah dengan harapan yang diciptakan oleh siswa bermuara pada kesenangan dan partisipasi siswa terhadap pelajaran. Hal tersebut didukung dengan fakta pada saat pengamatan yang dilakukan, pembelajaran IPS yang berlangsung di kelas V SD Gugus III Mengwi teramati berjalan efektif. Tetapi pada saat kegiatan pembelajaran berlangsung terlihat partisipasi siswa saat belajar IPS tergolong rendah dan beberapa siswa masih terlihat berdiskusi diluar materi yang sedang diajarkan, hal tersebut bisa menyebabkan kurang optimalnya pengetahuan siswa mengenai kompetensi pengetahuan IPS.

Kompetensi pengetahuan yang dicapai siswa tidak terlepas dari faktor internal dan faktor eksternal. Faktor internal yang memengaruhi kompetensi pengetahuan adalah kondisi fisik, seperti kesehatan organ tubuh, kondisi psikis seperti kemampuan intelektual, kecerdasan, sikap, dan kondisi sosial. Sedangkan faktor eksternal yang memengaruhi kompetensi pengetahuan yaitu adanya tingkat kesulitan materi belajar yang dipelajari, tempat belajar, iklim dan suasana lingkungan belajar.

Faktor internal yang memengaruhi kompetensi pengetahuan siswa mengacu kepada kecerdasan. Kecerdasan menurut Spearman dan Jones (dalam Uno 2012:58) "ada suatu konsepsi lama tentang kekuatan (power) yang dapat melengkapi akal pikiran manusia dengan gagasan abstrak yang universal, untuk dijadikan sumber tunggal pengetahuan sejati". Dalam perkembangan selanjutnya, pengertian inteligensi banyak mengalami perubahan, namun selalu mengandung bahwa intelegensi merupakan kekuatan atau kemampuan untuk melakukan sesuatu. Masyarakat umum mengenal intelegensi sebagai 
istilah yang menggambarkan kecerdasan, kepintaran ataupun kemampuan untuk memecahkan masalah yang dihadapi. Gardner (2013:59) menyatakan bahwa, "kecerdasan adalah potensi biopsikologis. Dalam hal apa seorang individu mungkin dianggap cerdas adalah produk dari warisan genetiknya dan sifat psikologisnya, yang terbentang dari kekuatan kognitif hingga kecenderungan kepribadianya". Kemudian, Gardner mengemukakan tujuh kecerdasan dasar, salah satunya yaitu kecerdasan intrapersonal.

Menurut Armstrong (2013:7) kecerdasan intrapersonal adalah "pengetahuan diri dan kemampuan bertindak secara adaptif berdasarkan pengetahuan itu. Kecerdasan ini termasuk memiliki gambaran yang akurat tentang diri sendiri (kekuatan dan keterbatasan seseorang); kesadaran terhadap suasana hati dan batin, maksud, motivasi, temperamen, dan keinginan serta kemampuan untuk mendisiplinkan diri, pemahaman diri dan harga diri." Sedangkan menurut Sholeh (2016:30) menyatakan "bahwa kecerdasan intrapersonal adalah kemampuan diri untuk berpikir kritis secara reflektif, yaitu mengacu pada kesadaran reflektif mengenai perasaan dan proses mengenai pemikiran diri sendiri. Adapun kegiatan yang mencakup kegiatan ini adalah berpikir, merancang tujuan, refleksi merenung, membuat jurnal dan menilai diri." Menurut Gardner (2013:31) menyatakan" kecerdasan intrapersonal pengetahuan aspek-aspek internal dari seseorang akses pada kehidupan perasaan seseorang sendiri, rentang emosi seseorang, kapasitas untuk membedakan emosi-emosi ini dan akhirnya memberi label dan menggunakannya sebagai sarana pemahaman memandu perilaku seseorang itu sendiri" Anak dengan kecerdasan intrapersonal yang menonjol memiliki kepekaan perasaan dalam situasi yang tengah berlangsung, memahami diri sendiri dan mampu mengendalikan diri dalam situasi konflik, serta mengetahui apa yang dapat dilakukan dan tidak dilakukan dalam lingkungan sosial dan mengetahui kepada siapa harus meminta bantuan saat memerlukan.

Selain kecerdasan intrapersonal faktor internal yang memengaruhi kompetensi pengetahuan siswa yaitu faktor sikap. Kuswana (2014:42), Sikap secara umum dalam konsep psikologi, didefinisikan sebagai evaluasi positif atau negatif dari orang, peristiwa, kegiatan, ide atau apa saja di lingkungan kita. Sikap adalah sesuatu yang dipelajari, dan sikap menentukan bagaimana individu bereaksi terhadap situasi serta menentukan apa yang dicari individu dalam kehidupan.

Sedangkan menurut Suyadi (2015:188) menyatakan sikap adalah "pendirian atau keputusan atas segala hal yang telah dipelajari dan diamati untuk merespons secara positif atau negatif terhadap permasalahan yang dihadapi." Salah satu sikap yang perlu dikembangkan pada siswa adalah sikap tanggung jawab. Kurniasih (2016: 36) menyatakan "tanggung jawab adalah sikap dan perilaku seseorang untuk melaksanakan tugas dan kewajibannya, yang seharusnya dia lakukan, terhadap diri sendiri, masyarakat, lingkungan (alam, sosial, budaya, dan budaya) negara dan Tuhan Yang Maha Esa". Namun adanya kesenjangan harapan dengan kenyataan yang terlihat masih terdapat beberapa siswa yang belum bertanggung jawab dalam hal mengerjakan tugas-tugas yang diberikan oleh guru seperti membuat tugas rumah (PR) yang dikerjakan di rumah, bukan di sekolah serta dikerjakan dengan tekun. Sehingga pada saat diadakan tes, siswa sudah mengerti dengan bahan ajar dan dapat mejawab soal tes dengan baik. Beberapa siswa juga terlihat belum melaksanakan kewajibanya dalam menjalankan tugas piket yang telah dijadwalkan hal tersebut menunjukan sikap tanggung jawab dari siswa perlu ditingkatkan.

Berdasarkan pemaparan yang telah diuraikan, bahwa perlu dioptimalkannya kompetensi pengetahuan IPS di SD yang disebabkan oleh faktor internal yaitu kecerdasan intrapersonal dan sikap tanggung jawab dimana kedua faktor tersebut saling berkaitan. Berdasarkan hasil wawancara dan observasi, menarik untuk dilaksanakan penelitian yang berjudul "Kontribusi Kecerdasan Intrapersonal dan Sikap Tanggung Jawab Terhadap Kompetensi Pengetahuan IPS Siswa Kelas V SD Gugus III Mengwi Tahun Pelajaran 2018/2019.

\section{Metode}

Tempat penelitian ini dilaksanakan yaitu pada siswa kelas V SD Gugus III Mengwi, Provinsi Bali yang terdiri dari 7 sekolah. Ketujuh sekolah tersebut adalah SD Negeri1 Sempidi, SD Negeri 2 Sempidi, SD Negeri 3 Sempidi, SD Negeri 1 Sading, SD Negeri 2 Sading, SD Negeri 3 Sading, SD Negeri 4 Sading Pemilihan SD Gugus III Mengwi Tahun Pelajaran 2018/ 2019 sebagai tempat penelitian karena keterjangkauan dan kelayakan. Keterjangkauan dalam arti tempat penelitian mudah dijangkau oleh peneliti, serta kelayakan dalam arti di SD Gugus III Mengwi belum pernah dilakukan penelitian yang sama dengan penelitian ini. Sekolah yang digunakan dalam penelitian ini juga dikarenakan sekolah tersebut memiliki persamaan kondisi serta fasilitasnya. 
Waktu penelitian berlangsung kurang lebih selama 6 bulan yang dimulai dari bulan Januari hingga bulan Juni tahun 2019. Waktu penelitian ini dimulai dari penyajian judul dan seminar proposal, pelaksanaan penelitian hingga penyusunan skripsi. Pelaksanaan penelitian diawali dengan melakukan penelitian pendahuluan, setelah itu melakukan pengumpulan data dan analisis data yang kemudian dilanjutkan dengan penyusunan skripsi.

Penelitian ini bertujuan untuk mengetahui seberapa besar kontribusi kecerdasan intrapersonal dan sikap tanggung jawab siswa terhadap kompetensi pengetahuan IPS siswa kelas V SD Negeri Gugus III Mengwi Tahun Ajaran 2018/2019, dengan tidak memanipulasi variabel bebas atau menggali fakta yang sudah terjadi sebelumnya sehingga penelitian ini tergolong penelitian ex post facto. Penelitian ex post facto adalah penelitian dengan mengambil kelompok-kelompok yang berbeda dan peneliti berusaha menentukan perbedaanperbedaan ini. Rancangan penelitian digambarkan sebagai berikut:

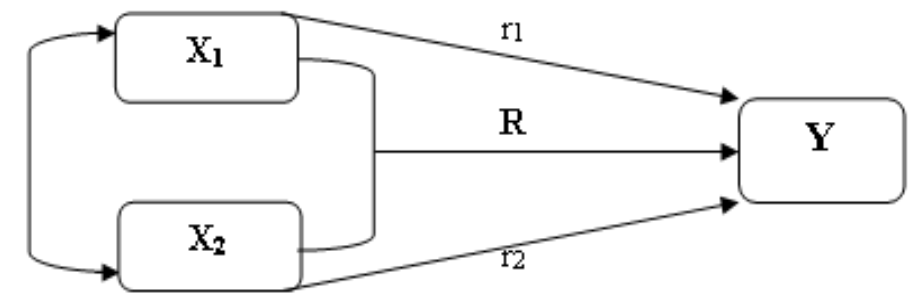

Gambar 01. Paradigma Ganda dengan Dua Variabel Independen (Sumber: Sugiyono, 2016:68)

Keterangan:

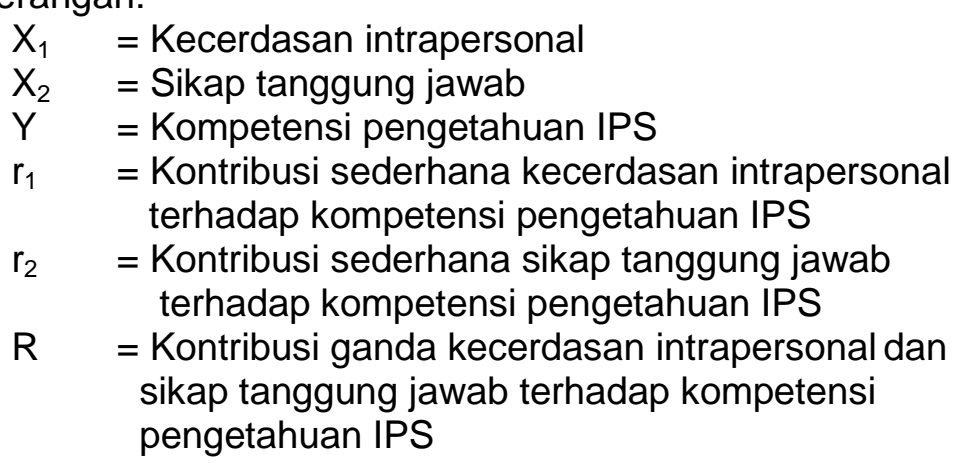

Dalam penelitian ini terdapat variabel bebas dan variabel terikat, variabel bebas menurut (sugiyono 2016:61) adalah variabel yang mempengaruhi atau yang menjadi sebab perubahannya atau timbulnya variabel dependen (terikat) Sedangkan menurut Agung (2014:42) variabel bebas yaitu satu atau lebıh dari variabel-variabel yang sengaja dipelajari pengaruhnya terhadap variabel tergantung. variabel bebas dalam penelitian ini adalah kecerdasan intrapersonal dan sikap tanggung jawab, sedangkan variabel terikat menurut (Agung:2013:43) adalah Variabel terikat disebut juga variabel tergantung yaitu variabel yang keberadaannya atau munculnya bergantung pada variabel bebas sedangkan menurut (Setyosari, 2012 : 129) Variabel terikat adalah aspek perilaku yang diamati dari organisme yang telah diberi stimulasi. Variabel terikat dalam penelitian adalah kompetensi pengetahuan IPS.

Metode pengumpulan data sangat penting digunakan dalam penelitian ini guna menjawab rumusan masalah penelitian. Penelitian ini sebagai upaya untuk memperoleh kebenaran yang didasari oleh proses berpikir ilmiah yang dituangkan dalam metode penelitian. Metode pengumpulan data yang digunakan pada penelitian di kelas V SD Gugus III Mengwi tahun ajaran 2018/2019 yaitu metode non tes. Data yang akan dianalisis dalam penelitian ini 
adalah data mengenai kompetensi pengetahuan IPS, Kecerdasan Intrapersonal dan Sikap Tanggung Jawab. Metode pengumpulan data yang akan digunakan adalah metode non tes.

Instrumen dalam bentuk angket atau kuesioner untuk memperoleh data kecerdasan intrapersonal dan sikap tanggung jawab. Sedangkan data kompetensi pengetahuan IPS diperoleh dari pencatatan dokumen. Kuesioner kecerdasan intrapersonal dibuat dengan beberapa indikator meliputi (1) sadar akan wilayah emosinya (2) menemukan cara-cara dan jalan keluar untuk mengepresikan perasaan dan pemikiranya (3) mengembangkan model diri yang akurat (4) termotivasi untuk mengidentifikasi dan memperjuangkan tujuanya (5) membangun dan hidup dengan suatu sistem nilai etik (agama) (6) bekerja mandiri (7) penasaran akan pertanyaan besar tentang makna, kehidupan relevansi dan tujuanya (8) mengatur secara kontinu pembelajaran dan perkembangan tujuan personalnya (9) berusaha mencari dan memahami pengalaman batinya sendiri (10) mendapatkan wawasan dalam kompleksitas diri dan eksistensi manusia (11) berusaha mengaktualisasikan diri (12) memberdayakan orang lain (memiliki tanggung jawab kemanusiaan). Sedangkan infikator sikap tanggung jawab meliputi (1) melaksanakan tugas individu dengan baik (2) menerima resiko dari tindakan yang dilakuikan (3) tidak menyalahkan/menuduh orang lain tanpa bukti yang akurat (4) mengembalikan barang yang dipinjam (5) mengakui dan meminta maaf atas kesalahan yang dilakukan (6) menepati janji (7) tidak menyalahkan orang lain untuk kesalahan kita sendiri (8) melaksanakan apa yang pernah dikatakan tanpa disuruh diminta.

Pengujian instrument dalam penelitian ini yaitu terdiri dari uji validitas dan uji reliabilitas. Instrument angket kecerdasan intrapersonal dan sikap tanggung jawab berjumlah 60 butir yang terdiri dari 30 butir pernyataan angket kecerdasan intrapersonal yang valid dan instrument angket sikap tanggung jawab terdiri dari 30 butir pernyataan yang valid. jawaban angket ini mengacu pada skala likert dengan empat alternative jawaban dengan rentang skor 1-4.

Sebelum dilakukan analisis terlebih dahulu dilakukan uji prasyarat analisis yang terdiri dari uji normalita Kolmogorov-Smirnov, uji linieritas, uji multikolinieritas dan uji heterokedastisitas.setelah uji prasyarat analisis dilanjutkan dengan uji hipotesis.uji hipotesis pertama dan kedua menggunakan analisis regresi linier sederhana. Sedangkan uji hipotesis ketiga menggunakan analisis regresi linier ganda. Uji hipotesis dilakukan untuk mengetahui tercapai atau tidaknya tujuan dalam penelitian ini. Adapun hipotesis yang diuji dalam penelitian ini yaitu: (1) Tidak terdapat pengaruh yang signifikan kecerdasan intrapersonal terhadap kompetensi pengetahuan IPS pada siswa Kelas V SD Gugus III Mengwi tahun pelajaran 2018/2019. (2) Tidak terdapat pengaruh yang signifikan sikap tanggung jawab terhadap kompetensi pengetahuan IPS pada siswa Kelas V SD Gugus III Mengwi tahun pelajaran 2018/2019.(3) Tidak terdapat pengaruh yang signifikan kecerdasan intrapersonal dan sikap tanggung jawab terhadap kompetensi pengetahuan IPS pada siswa Kelas V SD Gugus III Mengwi tahun pelajaran 2018/2019.

\section{Hasil dan Pembahasan}

Data mengenai kompetensi pengetahuan IPS siswa kelas V SD Gugus III Mengwi diperoleh melalui pencatatan dokumen, dokumen tersebut adalah daftar nilai ulangan akhir semester I, dengan meminta ijin kepada guru wali kelas masing-masing. Pencatatan dokumen sesuai dengan jumlah responden yaitu 164 responden.

Data tentang kecerdasan intrapersonal siswa kelas V SD Gugus III Mengwi diperoleh melalui penyebaran angket kecerdasan intrapersonal. Sampel yang dibagikan angket konsep diri sebanyak 164 responden dan diberikan dengan 30 pernyataan. Deskripsi data ini disajikan dengan Microsoft Excel 2013 serta disajikan juga dengan cara manual yang dimasukkan ke dalam tabel.

Data tentang sikap tanggung jawab siswa kelas V SD Gugus III Mengwi diperoleh melalui penyebaran angket sikap tanggung jawab. Sampel yang dibagikan angket sikap tanggung jawab sebanyak 164 responden dan diberikan dengan 30 pernyataan. Deskripsi data ini disajikan dengan Microsoft Excel 2013 serta disajikan juga dengan cara manual yang dimasukkan ke dalam tabel. 
Pengujian hipotesis pertama dengan analisis regresi sederhana diperoleh persamaan regresi $\hat{Y}=25,947+0,329 X_{1}$ signifikan dan linier. Persmaan regresi yang telah didapat berarti bahwa setiap kenaikan 1 kali satuan kecerdasan intrapersonal akan menyebabkan kenaikan 0,329 nilai kompetensi pengetahuan IPS pada konstanta 25,947 sehingga $\mathrm{H}_{0}$ yang menyatakan tidak terdapat pengaruh yang signifikan kecerdasan intrapersonal terhadap kompetensi pengetahuan IPS siswa Kelas V SD Gugus III Mengwi tahun pelajaran 2018/2019 ditolak dan $\mathrm{H}_{\mathrm{a}}$ diterima. Hasil analisis data diperoleh koefisien determinasi $\mathrm{R}^{2}=0,040$ dan kontribusinya sebesar $4 \%$. Hal ini berarti terdapat pengaruh yang signifikan kecerdasan intrapersonal terhadap kompetensi pengetahuan IPS siswa Kelas V SD Gugus III Mengwi tahun pelajaran 2018/2019 dan kontribusinya sebesar 4\%.

Pengujian hipotesis kedua dengan analisis regresi sederhana diperoleh persamaan regresi $\hat{Y}=25,744+0,335 X_{2}$ signifikan dan linier. Persamaan regresi yang telah didapat berarti bahwa setiap kenaikan 1 kali satuan sikap tanggung jawab akan menyebabkan kenaikan 0,335 nilai kompetensi pengetahuan IPS pada konstanta 25,744 , sehingga $\mathrm{H}_{0}$ yang menyatakan tidak terdapat pengaruh yang signifikan kecerdasan intrapersonal terhadap kompetensi pengetahuan IPS siswa Kelas V SD Gugus III Mengwi tahun pelajaran 2018/2019 ditolak dan $\mathrm{H}_{\mathrm{a}}$ diterima. Hasil analisis data diperoleh koefisien determinasi $R^{2}=0,039$ dan kontribusinya sebesar 3,9\%. $\mathrm{Hal}$ ini berarti terdapat pengaruh yang signifikan sikap tanggung jawab terhadap kompetensi pengetahuan IPS siswa Kelas V SD Gugus III Mengwi tahun pelajaran 2018/2019 dan kontribusinya sebesar 3,9\%.

Pengujian hipotesis ketiga dengan analisis regresi ganda diperoleh persamaan regresi $\hat{Y}=8,193+0,258 X_{1}+0,260 X_{2}$ signifikan dan linier. Persamaan regresi yang telah didapat berarti bahwa setiap kenaikan 1 kali satuan kecerdasan intrapersonal dan sikap tanggung jawab akan menyebabkan kenaikan 0,258 dan 0,260 nilai kompetensi pengetahuan IPS pada konstanta 8,193 sehingga $\mathrm{H}_{0}$ yang menyatakan tidak terdapat pengaruh yang signifikan kecerdasan intrapersonal dan sikap tanggung jawab terhadap kompetensi pengetahuan IPS siswa Kelas V SD Gugus III Mengwi tahun pelajaran 2018/2019 ditolak dan $\mathrm{H}_{\mathrm{a}}$ diterima. Hasil analisis data diperoleh koefisien determinasi $R^{2}=0,061$ dan kontribusinya sebesar $6,1 \%$. Hal ini berarti terdapat pengaruh yang signifikan kecerdasan intrapersonal dan sikap tanggung jawab terhadap kompetensi pengetahuan IPS siswa Kelas V SD Gugus III Mengwi dan kontribusinya sebesar $6,1 \%$.

Kompetensi pengetahuan yang dicapai siswa tidak terlepas dari faktor internal dan faktor eksternal. Faktor internal yang memengaruhi kompetensi pengetahuan adalah kondisi fisik, seperti kesehatan organ tubuh, kondisi psikis seperti kemampuan intelektual, kecerdasan, sikap, dan kondisi sosial. Sedangkan faktor eksternal yang memengaruhi kompetensi pengetahuan yaitu adanya tingkat kesulitan materi belajar yang dipelajari, tempat belajar, iklim dan suasana lingkungan belajar.

Faktor internal yang memengaruhi kompetensi pengetahuan siswa mengacu kepada kecerdasan. Kecerdasan menurut Spearman dan Jones (dalam Uno 2012:58) "ada suatu konsepsi lama tentang kekuatan (power) yang dapat melengkapi akal pikiran manusia dengan gagasan abstrak yang universal, untuk dijadikan sumber tunggal pengetahuan sejati”. Dalam perkembangan selanjutnya, pengertian inteligensi banyak mengalami perubahan, namun selalu mengandung bahwa intelegensi merupakan kekuatan atau kemampuan untuk melakukan sesuatu. Masyarakat umum mengenal intelegensi sebagai istilah yang menggambarkan kecerdasan, kepintaran ataupun kemampuan untuk memecahkan masalah yang dihadapi. Gardner (2013:59) menyatakan bahwa, "kecerdasan adalah potensi biopsikologis. Dalam hal apa seorang individu mungkin dianggap cerdas adalah produk dari warisan genetiknya dan sifat psikologisnya, yang terbentang dari kekuatan kognitif hingga kecenderungan kepribadianya". Kemudian, Gardner mengemukakan tujuh kecerdasan dasar, salah satunya yaitu kecerdasan intrapersonal.

Menurut Armstrong (2013:7) kecerdasan intrapersonal adalah "pengetahuan diri dan kemampuan bertindak secara adaptif berdasarkan pengetahuan itu. Kecerdasan ini termasuk memiliki gambaran yang akurat tentang diri sendiri (kekuatan dan keterbatasan seseorang); kesadaran terhadap suasana hati dan batin, maksud, motivasi, temperamen, dan keinginan 
serta kemampuan untuk mendisiplinkan diri, pemahaman diri dan harga diri." Sedangkan menurut Sholeh (2016:30) menyatakan "bahwa kecerdasan intrapersonal adalah kemampuan diri untuk berpikir kritis secara reflektif, yaitu mengacu pada kesadaran reflektif mengenai perasaan dan proses mengenai pemikiran diri sendiri. Adapun kegiatan yang mencakup kegiatan ini adalah berpikir, merancang tujuan, refleksi merenung, membuat jurnal dan menilai diri." Menurut Gardner (2013:31) menyatakan" kecerdasan intrapersonal pengetahuan aspekaspek internal dari seseorang akses pada kehidupan perasaan seseorang sendiri, rentang emosi seseorang, kapasitas untuk membedakan emosi-emosi ini dan akhirnya memberi label dan menggunakannya sebagai sarana pemahaman memandu perilaku seseorang itu sendiri" Anak dengan kecerdasan intrapersonal yang menonjol memiliki kepekaan perasaan dalam situasi yang tengah berlangsung, memahami diri sendiri dan mampu mengendalikan diri dalam situasi konflik, serta mengetahui apa yang dapat dilakukan dan tidak dilakukan dalam lingkungan sosial dan mengetahui kepada siapa harus meminta bantuan saat memerlukan.

Selain kecerdasan intrapersonal faktor internal yang memengaruhi kompetensi pengetahuan siswa yaitu faktor sikap. Kuswana (2014:42), Sikap secara umum dalam konsep psikologi, didefinisikan sebagai evaluasi positif atau negatif dari orang, peristiwa, kegiatan, ide atau apa saja di lingkungan kita. Sikap adalah sesuatu yang dipelajari, dan sikap menentukan bagaimana individu bereaksi terhadap situasi serta menentukan apa yang dicari individu dalam kehidupan. Sedangkan menurut Suyadi (2015:188) menyatakan sikap adalah "pendirian atau keputusan atas segala hal yang telah dipelajari dan diamatai untuk merespons secara positif atau negatif terhadap permasalahan yang dihadapi." Salah satu sikap yang perlu dikembangkan pada siswa adalah sikap tanggung jawab. Kurniasih (2016: 36) menyatakan "tanggung jawab adalah sikap dan perilaku seseorang untuk melaksanakan tugas dan kewajibannya, yang seharusnya dia lakukan, terhadap diri sendiri, masyarakat, lingkungan (alam, sosial, budaya, dan budaya) negara dan Tuhan Yang Maha Esa". Namun adanya kesenjangan harapan dengan kenyataan yang terlihat masih terdapat beberapa siswa yang belum bertanggung jawab dalam hal mengerjakan tugas-tugas yang diberikan oleh guru seperti membuat tugas rumah (PR) yang dikerjakan di rumah, bukan di sekolah serta dikerjakan dengan tekun. Sehingga pada saat diadakan tes, siswa sudah mengerti dengan bahan ajar dan dapat mejawab soal tes dengan baik. Beberapa siswa juga terlihat belum melaksanakan kewajibanya dalam menjalankan tugas piket yang telah dijadwalkan hal tersebut menunjukan sikap tanggung jawab dari siswa perlu ditingkatkan.

\section{Simpulan dan Saran}

Berdasarkan analisis yang telah dilaksanakan maka dapat disimpulkan bahwa 1) terdapat pengaruh yang signifikan kecerdasan intrapersonal terhadap kompetensi pengetahuan IPS siswa Kelas V SD Gugus III Mengwi tahun pelajaran 2018/2019 dan kontribusinya sebesar 4\%. Hal ini berarti, semakin tinggi tingkat kecerdasan intrapersonal siswa maka semakin tinggi kompetensi pengetahuan IPS siswa. 2) terdapat pengaruh yang signifikan sikap tanggung jawab terhadap kompetensi pengetahuan IPS siswa Kelas V SD Gugus III Mengwi tahun pelajaran 2018/2019 dan kontribusinya sebesar 3,9. Hal ini berarti, semakin tinggi tanggung jawab siswa maka semakin tinggi kompetensi pengetahuan IPS siswa 3) terdapat pengaruh yang signifikan kecerdasan intrapersonal dan sikap tanggung jawab terhadap kompetensi pengetahuan IPS siswa Kelas V SD Gugus III Mengwi tahun pelajaran 2018/2019 dan kontribusinya sebesar $6,1 \%$. Hal ini berarti, semakin tinggi tingkat kecerdasan intrapersonal dan tanggung jawab siswa maka semakin tinggi kompetensi pengetahuan IPS siswa.

Sebagai tindak lanjut dari hasil penelitian ini, maka beberapa saran dapat diberikan: 1) kepada siswa diharapkan selalu bersemangat dalam belajar, sehingga motivasi belajar siswa menjadi meningkat dan mampu dengan cepat mengerti dan memahami pembelajaran yang dipelajarinya, serta agar siswa memiliki sikap tanggung jawab yang baik. Dengan memiliki sikap tanggung jawab diharapkan siswa dapat memperoleh kompetensi pengetahuan yang baik. 2) kepada guru diharapkan untuk menggunakan berbagai inovasi dalam pembelajaran sehingga siswa tidak merasa jenuh dalam mengikuti pembelajaran yang diberikan oleh guru 
dan motivasi siswa dalam belajar dapat ditingkatkan. 3) kepada sekolah agar dapat menggunakan hasil penelitian ini sebagai pendukung sumber belajar guru dalam meningkatkan kualitas pendidikan dengan menumbuhkan dan mengembangkan kecerdasan intrapersonal dan sikap tanggung jawab siswa sehingga sekolah mampu menghasilkan siswa yang berkualitas. 4) Kepada peneliti lain diharapkan hasil penelitian ini digunakan sebagai referensi untuk melaksanakan penelitian selanjutnya.

\section{Daftar Pustaka}

Agung, A.A Gede. 2014. Metodelogi Penelitian Pendidikan. Singaraja: Universitas Pendidikan Ganesha.

Ahmadi, H.Abu.2016.Psikologi Sosial. Jakarta: RinekaCipta

Arikunto, Suharsimi. 2014. Dasar-Dasar Evaluasi Pendidikan. Jakarta: Bumi Aksara.

Armstrong, Thomas. 2013. Kecerdasan Multipel didalam Kelas. Terjemahan oleh Prabawaningrum, Widya. Jakarta : PT Indeks

Badan Standar Nasional Pendidikan, 2011. Standar Isi Untuk Satuan Pendidikan Dasar dan Menengah: Jakarta.

Dantes, Nyoman. 2012. Metode Penelitian. Yogyakarta: Andi.

Efendi, Fitri Mares. 2015. Hubungan Antara Kecerdasan Intrapersonal Dengan Prestasi Belajar Siswa Kelas IV Gugus I Kecamatan Srandakan Kavupaten Bantul Yogyakarta Tahun Ajaran 2014/2015. Yogyakarta :Universitas Negri Yogyakarta

Gardner, Howard. 2013. Multiple Intelligences. Terjemahan olehTerjemahan oleh Zainmur, Yelvi. Jakarta : Daras books

Gunawan, Rudy. 2013. Pendidikan IPS. Bandung : Alfabeta

Kosasih. 2014. Strategi Belajar dan Pembelajaran Implementasi Kurikulum 2013. Bandung: Yrama Widia

Kurniasih, Imas dan Berlin Sani. 2014. Ragam Pengembangan Model Pembelajaran Untuk Meningkatkan Profesionalitas Guru. Surabaya: Kata Pena.

Kurniasih, Imas dan Berlin Sani. 2016. Ragam Pengembangan Model Pembelajaran Untuk Meningkatkan Profesionalitas Guru. Surabaya: Kata Pena.

Koyan, I Wayan, 2014. Statistik Pendidikan. Singaraja: Universitas Pendidikan Ganesha Press.

Lasmawan. 2016 Pendidikan IPS. Bandung : Alfabeta

Mahesa, Dananjaya. 2018. Korelasi Antara Kecerdasan Intrapersonal dengan Kompetensi Pengetahuan IPS Siswa Kelas V SD Gugus Ubud Kecamatan Ubud Tahun 2017/2018. Universitas Pendidikan Ganesha

Murtie, Afin. 2016. Ensiklopedi Anak Berkebutuhan Khusus. Jogjakarta : Maxima

Narwati, Sri. 2011. Pendidikan Karakter. Yogyakarta; Familia.

Permendikbud 2016. Peraturan Menteri Pendidikan Dan Kebudayaan Nomor 24 Tahun 2016 Tentang Kompetensi Inti Dan Pendidikan Dasar Dan Pendidikan Menengah 
Permendiknas Nomor 22 tahun 2006 tentang standar isi pendidikan

Permendiknas Nomor 6 tahun 2007 tentang peraturan menteri pendidikan nasional

Pitri, Ari Lestari. 2018. Korelasi Antara Motivasi Belajar dan Sikap Tanggung Jawab Dengan Hasil Belajar IPA Siswa Kelas V SD Gugus III Kuta Utara Tahun Pelajaran 2017/2018. Universitas Pendidikan Ganesha

Setyosari, Punaji.2012. Metode Penelitian Pendidikan dan Pengembangan. Jakarta: Kencana

Sholeh, Khabib. 2016. Kecerdasan Majemuk Berorientasi Pada Partisipasi Peserta Didik. Yogyakarta; Pustaka Pelajar

Siregar, Syofian. 2015. Statistik Terapan Untuk Perguruan Tinggi. Jakarta: Pernadamedia Group

Slameto, 2010. Belajar \& Faktor-Faktor yang mempempengaruhinya, Jakarta; Rineka Cipta

Sugiyono. 2016. Statistik Untuk Penelitian. Alfabeta. Bandung

Sulistyowati, Endah. 2016. Implementasi Kurikulum Pendidikan Karakter. Yogyakarta; PT Citra Aji Parama

Sunaryo, Kuswana. 2014. Biopsikologi Pembelajaran Perilaku. Alfabeta. Bandung

Supardi. 2013. Aplikasi Statistika dalam Penelitian Konsep Statistika yang lebih Komprehensif. Jakarta: Change Publication

Susanto, Ahmad. 2014. Teori Belajar dan Pembelajaran di Sekolah Dasar Edisi Pertama. Jakarta: Kencana Prenada Media Group.

Sutrisno. Hadi. 2014. Metodelogi Penelitian Pendidikan. Jakarta: PT. Rineka Cipta

Suyadi, 2015. Menerapkan Pendidikan Karakter Di Sekolah. Mentari. Pustaka

Uno, Hamzah B. 2012. Orientasi Baru Dalam Psikologi Pembelajaran. Jakarta: PT. Bumi Aksara

Yusuf, Syamsu, dan Nami M. Sugandi. 2017. Asesment dan Evaluasi. Jakarta: PT Fajar Interpratama Mandiri 